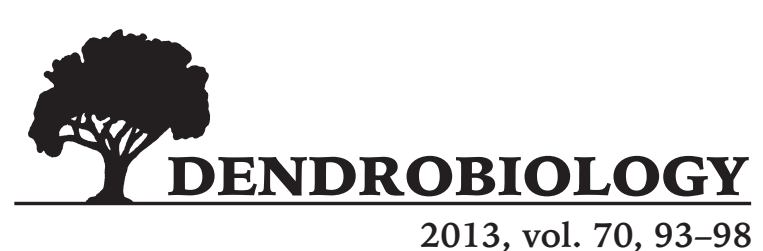

http://dx.doi.org/10.12657/denbio.070.010

\author{
Krzysztof Oklejewicz, Bohumil Trávníček, Mateusz Wolanin
}

\title{
New localities of Rubus clusii (Rosaceae) seriously expanding it range towards the East
}

\author{
Received: 22 October 2012; Accepted 14 March 2013
}

\begin{abstract}
Rubus clusii Borbás is a species which occurs in Central Europe, from southern Germany, Czech Republic, southwestern Slovakia, through western Hungary and Austria to Slovenia. Nine new localities of this taxon were found in southeastern Poland, which considerably extends its geographical range. The results of one study suggest that the present definition of the species range was based on incomplete data, missing its potential localities. Therefore, we expect further extension with more localities identified.
\end{abstract}

Additional key words: Rubus clusii, distribution, species new to Poland

Addresses: K. Oklejewicz, M. Wolanin, Department of Botany, Rzeszów University, Zelwerowicza 4, 35-601 Rzeszów, Poland, email: koklej@univ.rzeszow.pl

B. Trávníček, Department of Botany, Faculty of Science, Palacký University, Šlechtitelù 11, 78371 Olomouc, Czech Republic

\section{Introduction}

Rubus clusii Borbás is a species from the series Micantes Sudre of the subgenus Rubus. It is variable as far as the number of spines and glands on the stem is concerned. Specimens from semi-shaded localities are similar to Rubus gremlii Focke, from which they can be differentiated by having less hairy stems with numerous longer stalked glands; leaves in $R$. clusii are always green on the under side (often greyish green in R. gremlii, Matzke-Hajek 2004). They also have usually leaflets of leaves with a shorter apex. The specimens from sunny locations are unevenly covered by spines and they resemble taxa from the series Hystrix Focke, though the large number of glands and the more even distribution of spines corresponds more with the series Radula (Focke) Focke (Holub 1995; Weber 1995). Its range encompasses some parts of Central Europe, namely Czech Republic, SE Germany, E Austria, W Slovakia, W Hungary and N Slovenia
(Holub 1995; Weber 1995; Maurer and Drescher 2000; Lepší and Lepší 2004; Kurtto et al. 2010).

\section{Description of Rubus clusii}

Stems most often low-arching, angled, usually with flat sides, greenish or suffused brownish, with scattered simple and tufted hairs. The largest prickles 8-12 per $5 \mathrm{~cm}$ of stem lenght, straight, declining or slightly curved, 4-7 mm long, yellowish or reddish, often mixed with few (to numerous in sunny sites) needle-shaped pricklets, acicles (somewhat glandtipped) and stalked glands. Leaves on first-year stems digitate or subpedate, (3-)5-foliolate, usually dark green, glabrous or with scattered adpressed hairs above, rather densely patent-hairy beneath, without stellate hairs (Fig. 4). Leaflets \pm contiguous to slightly imbricate, terminal ones with mid-long petiolules (petiolule $\mathbf{3 0 - 3 7 \%}$ as long as its lamina), ovate to triangular broadly ovate, cordate at the base, 


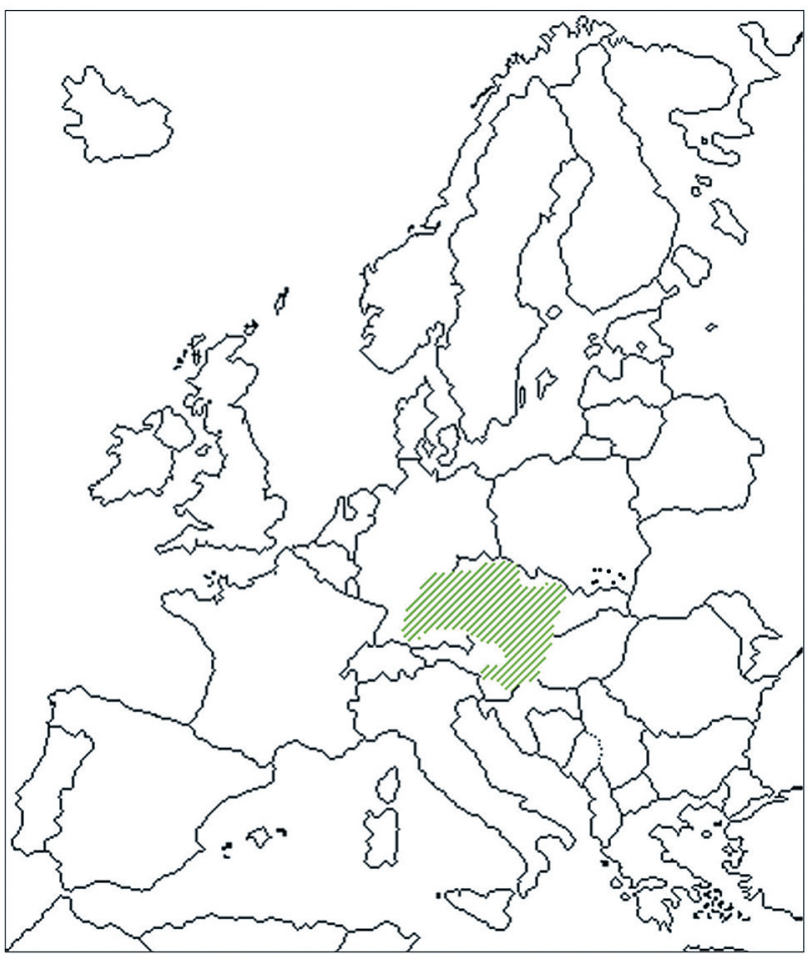

Fig. 1. New localities of Rubus clusii compared to its known range

with a gradually acuminate apex $8-15 \mathrm{~mm}$ long, \pm periodically serrate, serration $2-4 \mathrm{~mm}$ deep; teeth broad, apiculate, principal ones straight. Basal leaflets with petiolules $3-5 \mathrm{~mm}$ long. Petioles rather densely pubescent, with numerous stalked glands and 20-30 curved prickles. Stipules filiform. Inflorescence paniculate, usually narrow, almost cylindrical, leafy almost to the apex, with 3-foliolate leaves below (Fig. 6). Inflorescence axis with numerous simple and tufted patent hairs and rather numerous stalked glands, often with acicles. Larger prickles $8-20$ per 5 $\mathrm{cm}$ of axis length (Fig. 5), usually slightly curved, declining, (4-)5-7 mm long, often reddish-brown at the base. Pedicels 1-2 cm long, densely pubescent, with spreading hairs and $30-50$ stalked glands \pm as long as hairs. Prickles 6-13, slightly curved to straight, $1,5-2,5 \mathrm{~mm}$ long, yellowish. Sepals grey-green, with spreading hairs and numerous stalked glands, often with acicles, reflexed after anthesis. Petals white, \pm elliptical, 10-13 mm long (Fig. 7). Stamens white, somewhat longer than greenish styles. Anthers glabrous. Young carpels with hairs. Receptacle sparsely hairy. $-2 n=28$ (Krahulcová and Holub 1997). Flowering VI-VII.

\section{Results}

Newly found localities of Rubus clusii in SE Poland are isolated from its main distribution area (Fig. 1).

In Poland the species was recorded in 9 localities (Fig. 2):

1. Pogórze Strzyżowskie Foothills: Maga EF 7904 (N $49^{\circ} 59^{\prime} 28,56^{\prime}$ E $\left.021^{\circ} 20^{\prime} 36,93^{\prime \prime}\right)$, shrubbery of larch, leg. K. Oklejewicz 2001, edge of the shrubbery of larch, leg. K. Oklejewicz 2006;

2. Niepołomice Forest: Szarów EF $72 \quad 00 \quad$ (N $50^{\circ} 00^{\prime} 32,9^{\prime \prime} \mathrm{E} 020^{\circ} 15^{\prime} 29,3$ "), in a pine-oak forest, leg. K. Oklejewicz 11.07.2000;

3. Pogórze Dynowskie Foothills: Laskówka Kimlina FF 8613 (N 4952'5,38" E $\left.022^{\circ} 17^{\prime} 6,38^{\prime \prime}\right)$, edge of a larch forest, leg. K. Oklejewicz 10.10.2001;

4. Beskid Niski Mts: Łazy near Dukla FG 1232 (N $49^{\circ} 35^{\prime} 4,67^{\prime \prime}$ E $\left.021^{\circ} 41^{\prime} 5,63^{\prime \prime}\right)$, beech forest, near the edge, leg. J. Zieliński 17.08.1988;

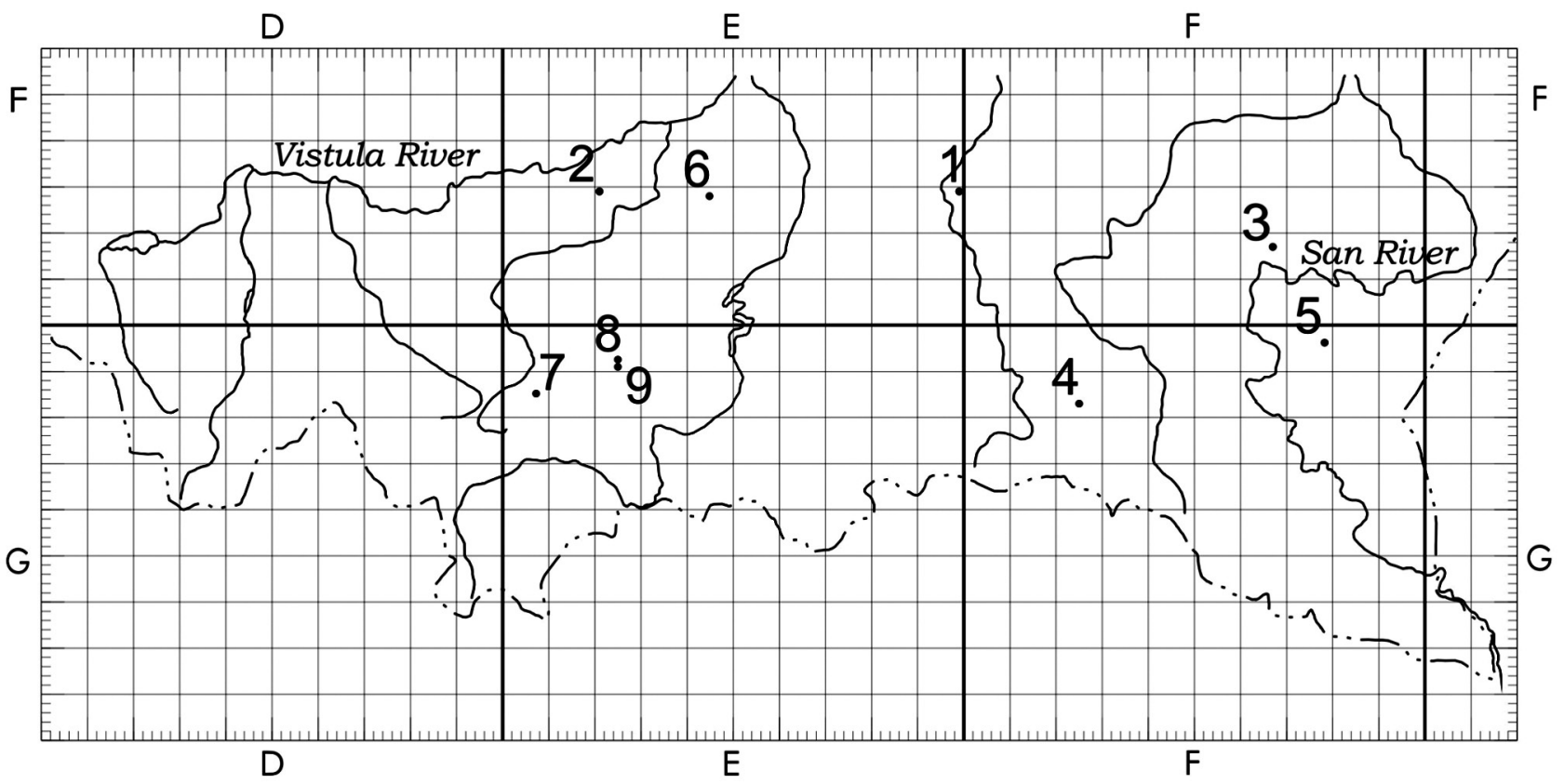

Fig. 2. New localities of Rubus clusii in the ATPOL grid (numbers used in the text) 


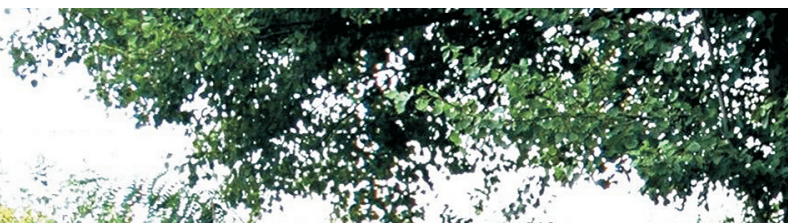

Fig. 3. Rubus clusii on the locality number 1 (photo K. Oklejewicz)

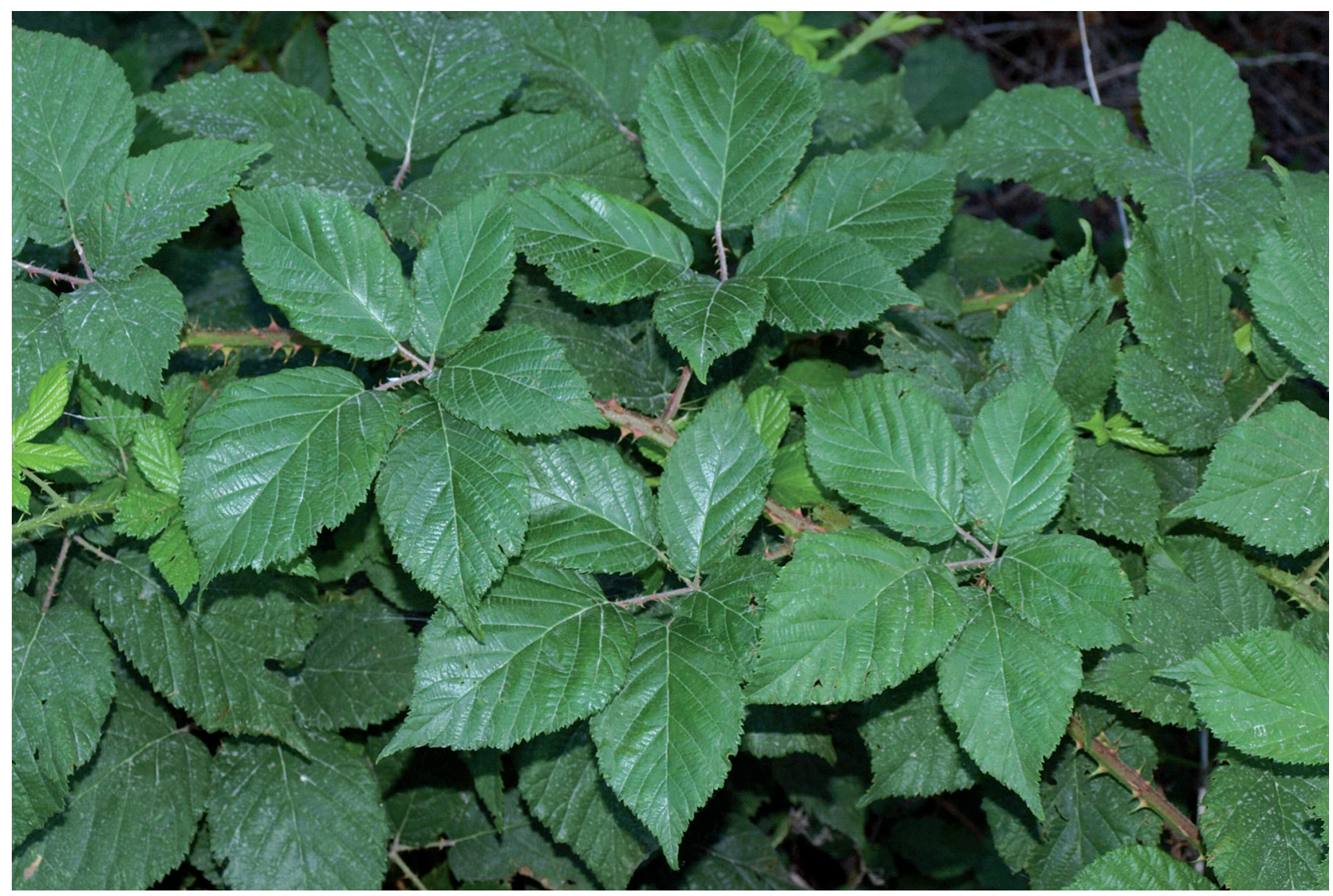

Fig. 4. Rubus clusii - leafy shoot (photo M. Wolanin) 


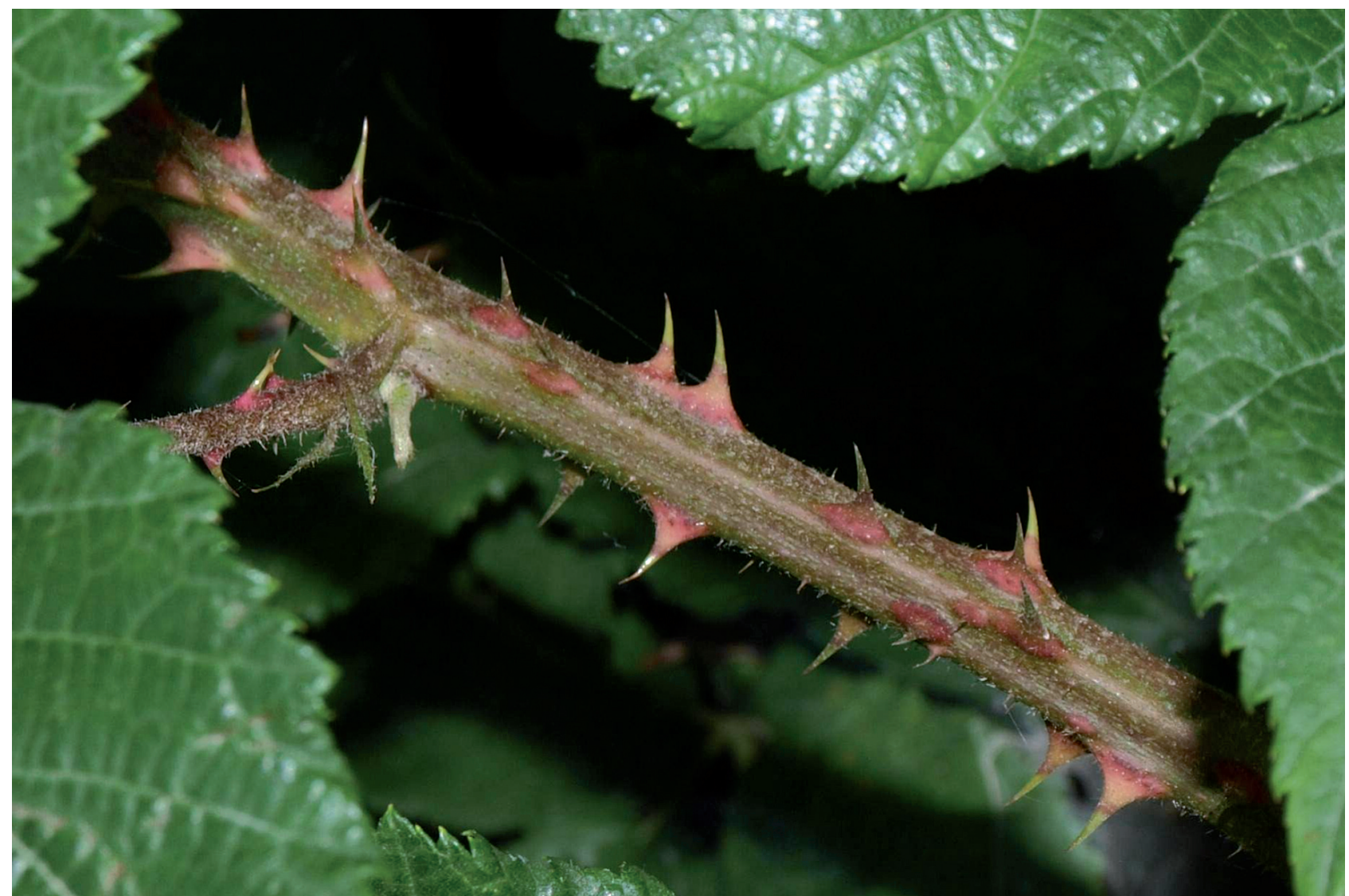

Fig. 5. Rubus clusii - stem (photo M. Wolanin)

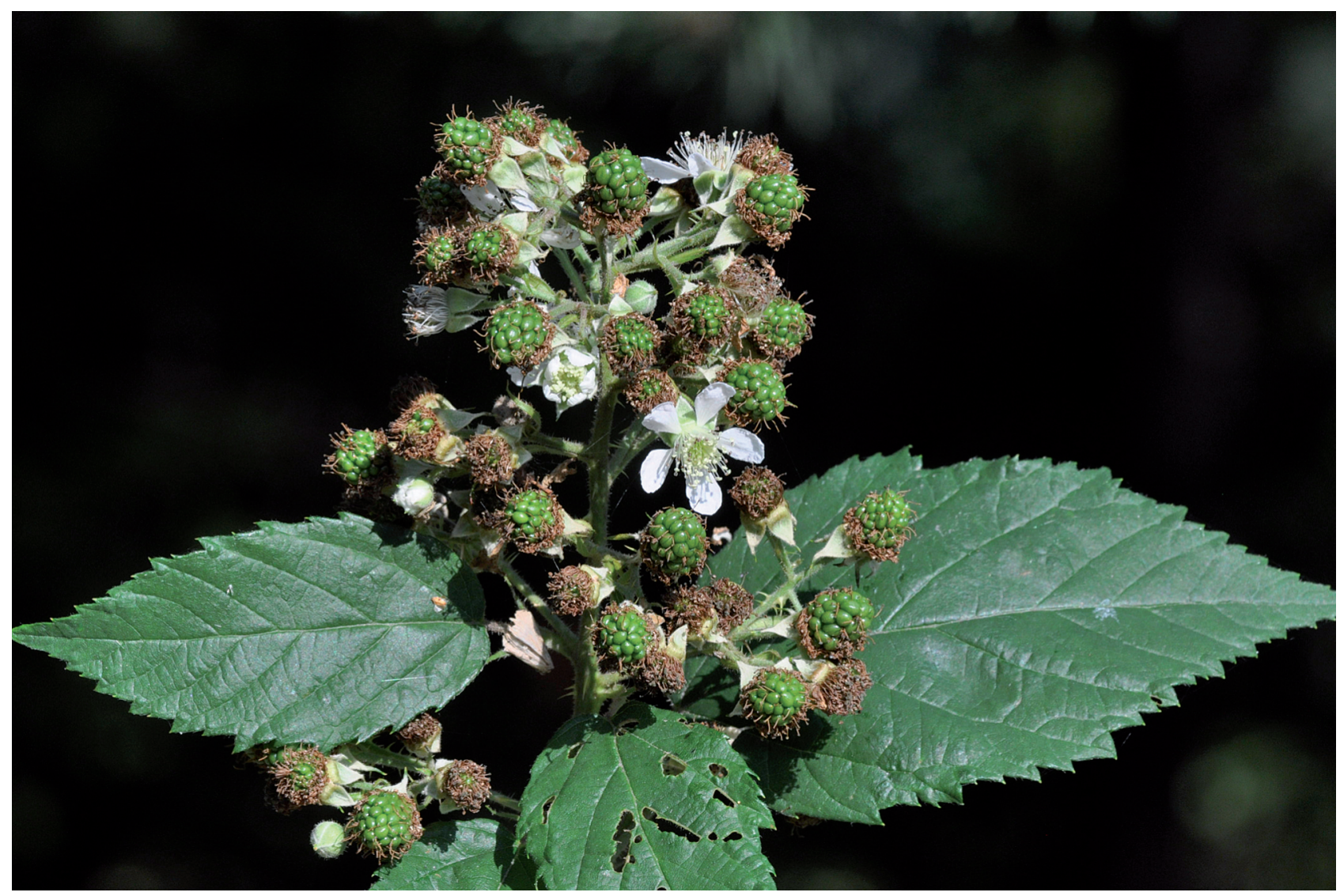

Fig. 6. Rubus clusii - inflorescence (photo M. Szewczyk) 


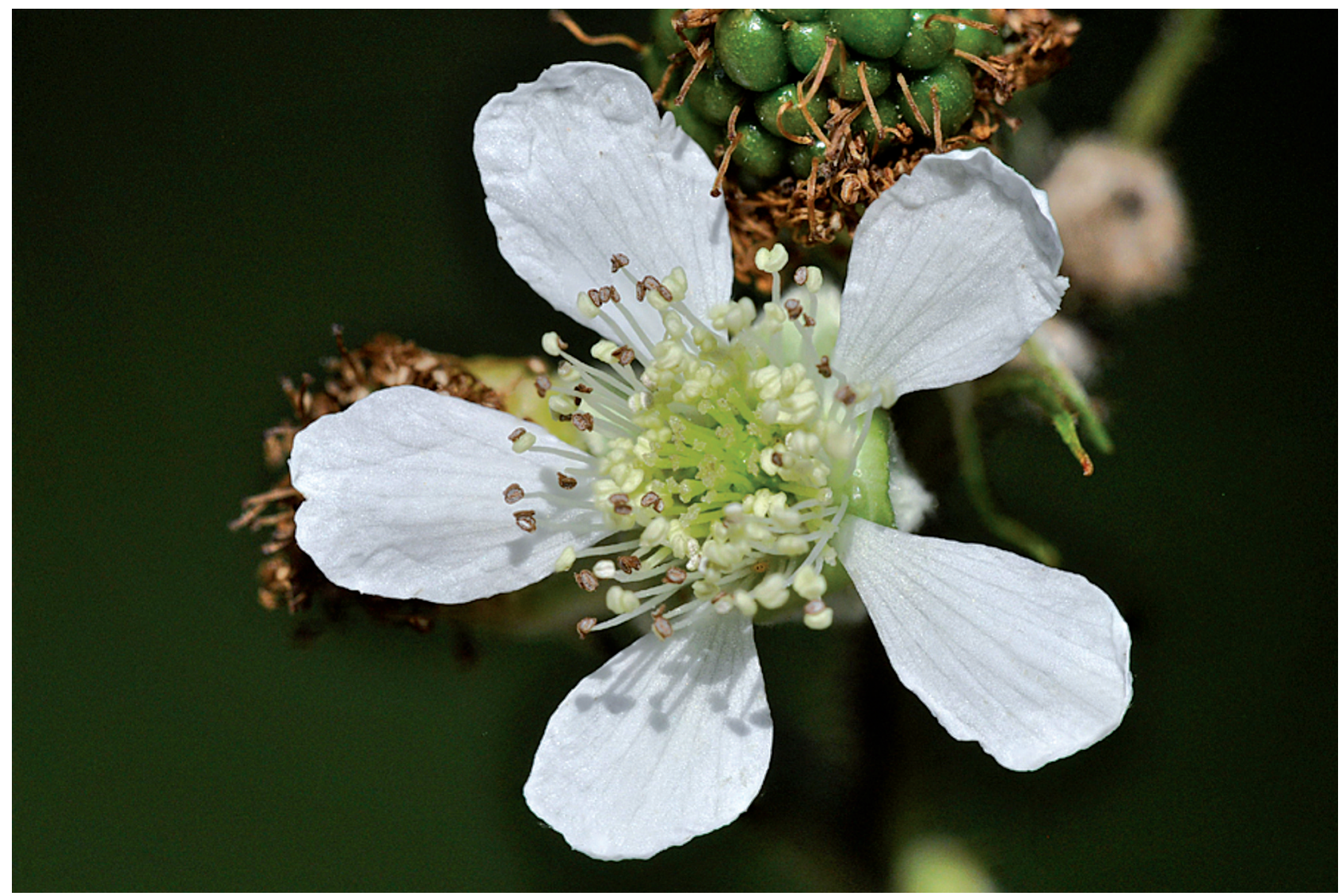

Fig. 7. Rubus clusii - flower (photo M. Szewczyk)

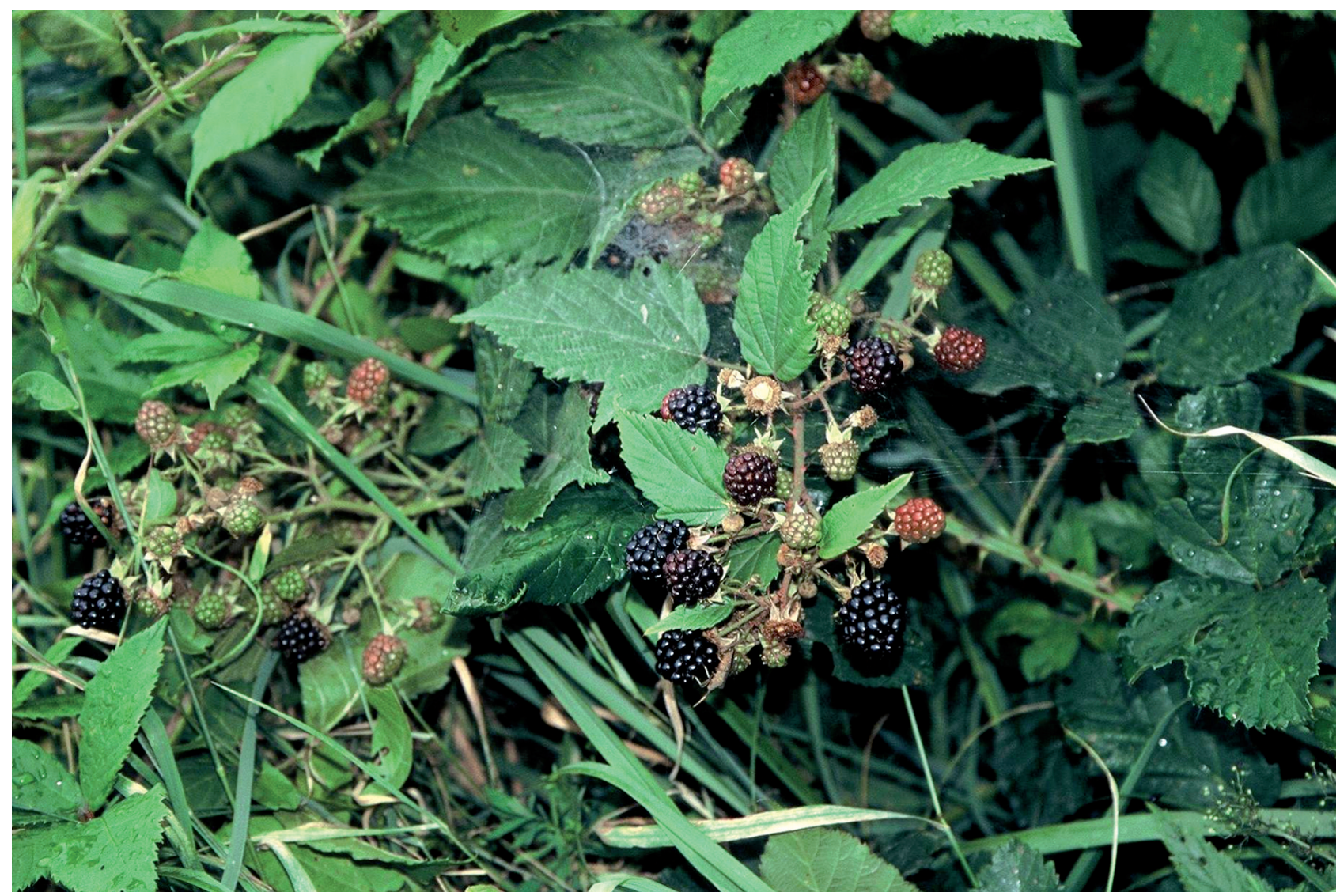

Fig. 8. Rubus clusii - fruitful shoot (photo K. Oklejewicz) 
5. Pogórze Przemyskie Foothills: Stara Bircza FG 07 14 (N 4940'38,91" E $\left.022^{\circ} 26 ' 7,72 "\right)$, shrubs near Stupnica stream, leg. M. Wolanin 30.07.2010;

6. Pogórze Wiśnickie Foothills: Brzesko-Okocim railway station EF $74 \quad 12 \quad\left(\mathrm{~N} 49^{\circ} 59^{\prime} 12,8^{\prime \prime}\right.$ E $\left.020^{\circ} 36^{\prime} 32,9^{\prime \prime}\right)$, slope near railway platform, leg. K. Oklejewicz 23.07.2012;

7. Gorce Mts: Poręba Wielka EG 1023 (N 49³7'15.9" E $\left.020^{\circ} 33^{\prime} 37,3^{\prime \prime}\right)$, near the way across the forest, leg. K. Oklejewicz 24.07.2012;

8. Beskid Wyspowy Mts: Słopnice Królewskie EG 02 32 (N 4940'51,9" E $020^{\circ} 18^{\prime} 07,1^{\prime \prime}, \mathrm{N} 49^{\circ} 41^{\prime} 48,2^{\prime \prime}$ E $\left.020^{\circ} 18^{\prime} 52,1^{\prime \prime}\right)$, the edge of the forest with Abies alba and Fagus sylvatica, leg. K. Oklejewicz 24.07.2012;

9. Beskid Wyspowy Mts: Słopnice Królewskie EG 02 42 (N 4940'47,0" E $\left.020^{\circ} 18^{\prime} 03,0^{\prime \prime}\right)$, the edge of the forest with Abies alba and Fagus sylvatica, leg. K. Oklejewicz 24.07.2012.

The largest one was found in 2001 in a hamlet of Maga (1) in the Strzyżów Foothills (2 km ATPOL grid - EF 7904). Originally a few individuals grew in a Larix decidua subsp. decidua stand. The site was characterized by the following phytosociological releve:

A larch grove, sand soil, $\mathrm{S}$ slope of $3^{\circ}$, area $100 \mathrm{~m}^{2}$, cover: A 70\%; B 10\%, C 100\%. Trees and shrubs: A Larix decidua subsp. decidua 3.3, Pinus sylvestris + , B: Sorbus aucuparia + , Robinia pseudoacacia + , Populus tremula + , Quercus robur + , Sambucus nigra + , C: Rubus clusii 1.2, R. idaeus 2.2, $R$. hirtus 5.5, Calamagrostis epigejos +, Agrostis capillaris +, Galium mollugo +, Urtica dioica + . In the following five years the species expanded its cover and large clumps of $R$. clusii with a $100 \%$ cover appeared between the road and the tree stand. This is illustrated by the following releve:

SE slope $\left(10^{\circ}\right)$, between a road and a Populus tremula and Fagus sylvatica grove, area $100 \mathrm{~m}^{2}$, cover $100 \%$; Rubus clusii 5.5, R. idaeus +, Urtica dioica + , Arrhenatherum elatius + , Solidago gigantea + , Tanacetum vulgare + , Equisetum arvense + , Achillea millefolium + , Erigeron annuus +, Galium mollugo +, Convolvulus arvensis + , Agropyron repens + .

Single individuals were also found in the Niepołomice Forest - Szarów, in a pine-oak forest (2), in the Dynów Foothills - Laskówka Kimlina, edge of a larch forest (3), at the edge of the Beskid Niski Mts. - Łazy near Dukla, beech forest, near the edge (4) and in the Przemyśl Foothils - Stara Bircza, shrubs near Stupnica stream (5). In the year 2012 we found four new localities: Brzesko-Okocim (6), Poręba Wielka (7) and Słupnice $(8,9)$.

\section{Conclusion}

They newly found localities of Rubus clusii from Poland extend the border pf its range eastwards. The stands seem to be composed of small, young clumps which suggests that the species may be actively changing its general range. On the other hand the localities may have been simply overlooked.

\section{Acknowledgements}

We thank Professor Jerzy Zieliński (Institute of Dendrology, Polish Academy of Sciences, Kórnik) for providing his herbarium material of Rubus clusii. We thank also Marian Szewczyk for Rubus clusii inflorescence and flower photos. This study was supported by the Grant Agency of the Czech Republic (grants no. 206/99/0771, 206/07/0706 and 206/08/0890).

\section{References}

Holub J. 1995. 4. Rubus L. - ostružiník (maliník, moruška, ostružinec, ostružiníček), pp. 54-206. In: Slavík B. (ed.), Kvìtena České Republiky, Vol. 4, Academia, Praha.

Krahulcová A., Holub J. 1996. Chromosome number variation in the genus Rubus in the Czech Republic. I. Preslia 68: 241-255.

Kurtto A., Weber H. E., Lampinen R., Sennikov A. N. (eds.) 2010. Atlas Florae Europaeae. Distribution of Vascular Plants in Europe. 15. Rosaceae $(R u-$ bus). The Committee for Mapping the Flora of Europe \& Societas Biologica Fennica Vanamo, Helsinki.

Lepší M., Lepší P. 2004. Rozšíření rodu Rubus v prýrodním parku Novohradské hory (jižní Čechy). Zprávy České Botanické Společnosti 39: 249-283.

Matzke-Hajek G. 2004. Was ist Rubus gremlii Focke? Berichte der Bayerischen Botanischen Gesellschaft 73/74: 17-34.

Maurer W., Drescher A. 2000. Die Verbreitung einiger Brombeerarten (Rubus subgen. Rubus) in Österreich und im angrenzenden Slowenien. Mitteilungen des Naturwissenschaftlicher Verein für Steiermark 130: 141-168.

Weber H. E. 1995. 4. Rubus., pp. 285-595. In: Hegi G. 1995. Illustrierte Flora von Mitteleuropa, ed. 3, Vol. 4/2A, Blackwell Wissenschafts-Verlag, Berlin, Oxford. 